\title{
Women Households Empowerment, Decisive Role, Participation for Agriculture and Rural Economy in South Asia: A Case Study of Haryana
}

\author{
Dr. Raj Kumar \\ Extension Lecturer, Department of Economics \\ I.G. Govt. P.G. College, Tohana, Fatehabad, \\ Haryana, India
}

\author{
Brij Mohan Krishan Shorey \\ Statistical Investigator Grade-I, \\ Directorate of Census Operations, Hotel Khyam Buiilding, \\ Bishember Nagar, Srinagar
}

\begin{abstract}
An attempt has been made in the paper to explore to the extent women empowerment affected the conditions of rural women engaged in agriculture and related household activities. Results of the study show that there isn't much improvement in women's power in regard to take decisions in agriculture and household activities in the rural agrarian economy. Women headed households occupying houses made up of burnt brick is more in rural (53.65 per cent) in comparison to urban (33.23 per cent). Only 17 percent women are taking final decision regarding selling and purchasing of animals in the present agrarian economy in rural areas. The formation of policy making regarding women empowerment should be improved and implemented in properly so that they have benefited.
\end{abstract}

\section{Keywords}

Women-Empowerment, Policy-Formulation, Decision-Making Process, Empowered-Women, and Rural Agrarian Economy.

\section{INTRODUCTION}

Numerous policies have been formulated in the past seventy years especially for India's rural agrarian structure; initially in rural area's development and for the growth of women empowerment. In actual the real effect of these policies formulations is not seen to the required impact neither in economic, social, political and nor for the domestic conditions of rural women in agrarian structure regarding their decision making power in different areas. Role they play in rural is significant in agriculture and allied activities in the farm management. Despite their concerned work is completed by themselves, final control on decision resides within male dominant society. Numerous research studies by the policy makers, researchers and academician related to it in the era of women empowerment have mostly the common results on exploitation regarding their decision making power which has not increased even after improvement in background state of women through developed educationally, socially, politically and domestically. In the present era, the decision making participation in agrarian economy in the rural agriculture is although hundred percent for work done by the women in the fields but their decision making participation is very low after a long duration in independent India. The situation and circumstances are questionable?

\subsection{Objectives of the Study}

- To analyze the present situation of decision making participation of women in agrarian economy related to agriculture and household activities in rural economy.

- To know status up to the extent of rural women in decision making exists regarding with agriculture and house hold activities.
- To study after 70 years of independence and implementation of women empowerment to the extent improvement in their conditions in agrarian economy and living standards.

\subsection{Research Methodology}

Both primary data collected and secondary analytically utilized to fulfill objectives of the study. Likewise data to examine decision making power in rural areas in agrarian structure in agriculture and house hold activities from different sources are utilized. A three degree likert scale questionnaire developed on different aspects regarding agricultural and household activities in rural areas. More than ten statements were canvassed through questionnaire by approaching hundred women of two villages of District Hisar in Haryana. Data collected using surveying method from respondents by personally interviewing with a planned structured questionnaire. Secondary data used and analyzed rom different sources published by the government organizations available online. Simple percentage also has been used to know to what extent decision making participation in agriculture and house hold activities affected, their living standard improved after women empowerment.

\subsection{Review of Literature}

\subsubsection{Kumar and Ahmed (1984)}

analyzed that there are greatest spatial variations in women participation in Haryana, Punjab, West Bengal Andhra Pradesh and Maharashtra whereas in southern states more participation than northern states regarding economic, socio and demographic factors affects is quite visible

\subsubsection{Hoque and Itohara (2008)}

study revealed that even after formulation of appropriate strategy women empowerment (participation) has remained below than the expectations in decision making. Their study also disclosed that NGO women's participation was better than Non- NGO in decision making power as training facilities of the NGO's increased subsequently following their participation.

\subsubsection{Farid et. al. (2009)}

has written that a significant role is played by the women in agriculture or non-agriculture activities like harvesting or post harvesting activities and homestead gardening.

\subsubsection{Singh (2011)}

study concluded about drastic change in decision making power of the rural women from economic point of view, but discrimination in wage doing same work either in agriculture, industries or other activities cannot be overlooked. 


\subsubsection{Hussain and Hussain (2011)}

regarding socio economic status of women that affect the decision making process at home or farm management explores that their participation in decision making is influenced by various factors such as nature of the household and employment of husband.

\subsubsection{IFAD International Fund for Agriculture Fund (2011)}

the study revealed that after empowerment on socio-economic side they potential to changes in the rural areas, household activities and agriculture production. But as the inequalities exist, on this account their potential hasn't been utilized.

\subsubsection{Tsegaye et. al. (2012)}

has written that major of the house hold responsibilities and of the maximum women is taking care of seed production. In fact all significant works are done by them but their decision making involvement and final decision is quite lesser. The study recommends for improvement in their condition regarding final decision making.

\subsubsection{Behera and Behera (2013)}

examined that rural women play significant role in agriculture and allied activities like from crop production, livestock production to cottage industries, even then socially, economically, and politically their status is low, however the study recommends that there shouldn't be exploitation by the landlord.

\subsubsection{Sharma et.al. (2013)}

has written that contribution of women in Indian agriculture is significant. However, majority of management decisions in rural areas are taken by head of the household (Head of $\mathrm{HH}$ ). The decisions are being taken up by Head of $\mathrm{HH}$ for buying-selling of land, machine-agriculture implements, and livestock etc.

\subsubsection{Mohanty et. al. (2013)}

self-help group enhanced their decision making power economically and this reduced their dependency. Also their financial resources capacity greatly influenced decision making process in the rural areas.

\subsubsection{Balyan (2014)}

found that after a significant contribution in economic activities only in domestic matters i.e. decoration of house, purchase of domestic goods, making a chulha choka, marriage of children the women are giving freedom for their own decision but in other matters no importance is given to them in Indian society.

\subsubsection{Mahata et. al. (2017)}

on account of female participation increase presents that picture of male dominant society can be changed like state of Haryana. Number of scheme have been launched by the State and Central Government to achieve the objective i.e. Beti Bachao Beti Padhao Abhiyan.

\subsection{Discussion and results of Primary data analysis}

Table 1: Awareness and Decision making Participation regarding Saving Activities

\begin{tabular}{|l|l|l|l|}
\hline To some exten & Yes & No & Total \\
\hline $\mathbf{1}$ & $\mathbf{2}$ & $\mathbf{3}$ & $\mathbf{4}$ \\
\hline $62 \%$ & $21 \%$ & $17 \%$ & 100 \\
\hline
\end{tabular}

Source: Primary Data
Table 1 shows that $62 \%$ women in rural areas accept involvement in decision making to some extent whereas $17 \%$ responded for no consideration in decision making process despite having perfect knowledge \& awareness about saving activities in agriculture. 21 $\%$ women responded to final decision in agriculture and $\mathrm{HH}$ activities in rural agrarian economy.

Table 2: Knowledge regarding Cash Crops and Decision making

\begin{tabular}{|l|l|l|l|}
\hline Only consulted & Opinion consider & Final Decision & Total \\
\hline $\mathbf{1}$ & $\mathbf{2}$ & $\mathbf{3}$ & $\mathbf{4}$ \\
\hline $50 \%$ & $34 \%$ & $16 \%$ & 100 \\
\hline
\end{tabular}

Sources: Primary Data

Table 2 reveals that 50 percent women are only consulted regarding cash crops, opinion of 34 percent women are considered and there are only 16 percent women whosever final decision are being taken up in growing cash crops as and they have sufficient knowledge.

Table 3: Final Decision regarding Purchasing or selling of Farm Machinery

\begin{tabular}{|l|l|l|}
\hline Only consulted & Opinion considered & Final decision \\
\hline $\mathbf{1}$ & $\mathbf{2}$ & $\mathbf{3}$ \\
\hline $60 \%$ & $21 \%$ & $19 \%$ \\
\hline \multicolumn{2}{|l|}{ Sources: Primary Data }
\end{tabular}

In present agrarian economy some tasks are being completed by machines due to the necessity of faster purchasing and selling activity. In this aspect 19 percent women responded about their final decision; another 60 percent are only consulted whereas opinion is considered for 21 percent.

Table 4: Decision and Awareness regarding Purchasing of Agriculture Inputs and Finance

\begin{tabular}{|l|l|l|}
\hline Banking facilities & $\begin{array}{l}\text { Co-operative } \\
\text { societies }\end{array}$ & Others Resources \\
\hline $\mathbf{1}$ & $\mathbf{2}$ & $\mathbf{3}$ \\
\hline $12 \%$ & $20 \%$ & $68 \%$ \\
\hline
\end{tabular}

Sources: Primary Data

Above table is related to finance decisions through various sources. It is reported that 12 percent women have awareness about banking facilities (being availed by family), 20 percent are utilizing cooperative society for finance and remaining 68 percent women are using other sources for input in agriculture.

Table 5: Final Decision regarding Changing Cropping Pattern in the Farm

\begin{tabular}{|l|l|l|}
\hline Only consulted & Opinion considered & Final decision \\
\hline $\mathbf{1}$ & $\mathbf{2}$ & $\mathbf{3}$ \\
\hline $50 \%$ & $30 \%$ & $20 \%$ \\
\hline
\end{tabular}

Sources: Primary Data

Table 5 presents that decisions regarding changing cropping pattern in the farm; only 20 percent women are making their final decision, 50 percent are only consulted and opinion of 30 percent are considered. It is noticeable that the decision making power of women in agriculture also is very low although most of the works have been done by the women regarding this area.

Table 6: Final Decision regarding Purchasing or Selling of Animals

\begin{tabular}{|l|l|l|}
\hline Only consulted & Opinion considered & Final decision \\
\hline $\mathbf{1}$ & $\mathbf{2}$ & $\mathbf{3}$ \\
\hline $52 \%$ & $21 \%$ & $17 \%$ \\
\hline
\end{tabular}

Sources: Primary data 
Table 6 depicts that only 17 percent women are taking final decision regarding selling and purchasing of animals in the present agrarian economy in rural areas. However, 52 percent are only consulted and opinion of 21 percent women is considered in agriculture decision making.

\subsection{Secondary Data Sources Analysis}

After independence rather say in the history Indian Censuses release of data on houses, household amenities and assets exclusively for the women headed households depicts the rea living status of women in the society. Haryana is among the states where less than 10 per cent women have been as head of the household. Haryana reported female headed households as 9.5 per cent followed by Gujarat as 9.0 per cent and Capital of the State (Chandigarh) as 8.9 per cent. It is apparent that highly urban area Chandigarh has reported lesser account of women headed households (WHH) in comparison to Haryana.

Table 7: Material of Wall of Census Houses Occupied by Women Headed Households

\begin{tabular}{|c|c|c|c|c|c|c|}
\hline \multirow[t]{3}{*}{ Type of Material } & \multicolumn{6}{|c|}{ Material of Wall } \\
\hline & \multicolumn{2}{|l|}{ Total } & \multicolumn{2}{|l|}{ Rural } & \multicolumn{2}{|l|}{ Urban } \\
\hline & Absolute & Per cent & Absolute & Per cent & Absolute & Per cent \\
\hline 1 & 2 & 3 & 4 & 5 & 6 & 7 \\
\hline All Material & 449,366 & 100.00 & 275,867 & 61.39 & 173,499 & 38.61 \\
\hline Grass/thatch/bamboo etc. & 2,896 & 0.64 & 1,995 & 0.44 & 901 & 0.20 \\
\hline Plastic/ Polythene & 767 & 0.17 & 270 & 0.06 & 497 & 0.11 \\
\hline Mud/unburnt brick & 20,681 & 4.60 & 13,997 & 3.11 & 6,684 & 1.49 \\
\hline Wood & 355 & 0.08 & 147 & 0.03 & 208 & 0.05 \\
\hline Stone not packed with mortar & 7,167 & 1.59 & 3,678 & 0.82 & 3,489 & 0.78 \\
\hline Stone packed with mortar & 18,229 & 4.06 & 11,304 & 2.52 & 6,925 & 1.54 \\
\hline G.I./ metal/asbestos sheets & 320 & 0.07 & 110 & 0.02 & 210 & 0.05 \\
\hline Burnt brick & 390,406 & 86.88 & 241,080 & 53.65 & 149,326 & 33.23 \\
\hline Concrete & 8,030 & 1.79 & 3,025 & 0.67 & 5,005 & 1.11 \\
\hline Any other & 515 & 0.11 & 261 & 0.06 & 254 & 0.06 \\
\hline
\end{tabular}

Source: http://www.censusindia.gov.in/2011census/hlo/hlo_table/hlo_table_Haryana.html

Above table 7 provides details of the material used for walls of the census houses occupied by women. Women have been living in houses having walls made up of mud/unburnt brick of 13,997 households in rural and 6,684 in urban. Women headed households residing in houses having wall made up of material
Grass/thatch/bamboo etc. of 2,896 houses and of plastic/polythene of 767 houses. However, women headed households occupying houses made up of burnt brick is more in rural (53.65 per cent) in comparison to urban (33.23 per cent).

Table 8: Material of Roof of Census Houses Occupied by Women Headed Households

\begin{tabular}{|c|c|c|c|c|c|c|}
\hline \multirow[t]{3}{*}{ Type of Material } & \multicolumn{6}{|c|}{ Material of Roof } \\
\hline & \multicolumn{2}{|l|}{ Total } & \multicolumn{2}{|l|}{ Rural } & \multicolumn{2}{|l|}{ Urban } \\
\hline & Absolute & Per cent & Absolute & Per cent & Absolute & Per cent \\
\hline 1 & 2 & 3 & 4 & 5 & 6 & 7 \\
\hline All Material & 449,366 & 100.00 & 275,867 & 61.39 & 173,499 & 38.61 \\
\hline Grass/thatch/bamboo etc. & 98,013 & 21.81 & 79,179 & 17.62 & 18,834 & 4.19 \\
\hline Plastic/ Polythene & 1,516 & 0.34 & 565 & 0.13 & 951 & 0.21 \\
\hline Handmade tiles & 18,915 & 4.21 & 15,953 & 3.55 & 2,962 & 0.66 \\
\hline Machine made tiles & 6,004 & 1.34 & 3,687 & 0.82 & 2,317 & 0.52 \\
\hline Burnt brick & 67,567 & 15.04 & 51,549 & 11.47 & 16,018 & 3.56 \\
\hline Stone/ Slate & 106,647 & 23.73 & 75,023 & 16.70 & 31,624 & 7.04 \\
\hline G.I./metal/asbestos sheet & 8,318 & 1.85 & 3,995 & 0.89 & 4,323 & 0.96 \\
\hline Concrete & 140,789 & 31.33 & 45,001 & 10.01 & 95,788 & 21.32 \\
\hline Any other & 1,597 & 0.36 & 915 & 0.20 & 682 & 0.15 \\
\hline
\end{tabular}

Source: http://www.censusindia.gov.in/2011census/hlo/hlo_table/hlo_table_Haryana.htm

The best place ever to survive is considered with kind of shelter available for the household. It is observed that from the above table that 17.62 per cent of the rural population is living in a type of census house with the roof made up of grass/thatch/bamboo etc. Besides this houses in possession of the households (women headed) having roof of stone/slate ( 16.70 per cent) and burnt brick (11.47 per cent) is higher as compared to urban. Households 
$(140,789)$ occupying house roof made of concrete material is higher in urban (21.32 per cent). Table- 8 .

Table 9 presents that houses flooring condition is better as out of the total houses in possession of the households (women headed) is 23.70 per cent in rural and 20.93 per cent in urban. On the other side 23.38 per cent households are having floor made up of mud in rural.

Table 9: Material of Floor of Census Houses Occupied by Women Headed Households

\begin{tabular}{|c|c|c|c|c|c|c|}
\hline \multirow[t]{3}{*}{ Type of Material } & \multicolumn{6}{|c|}{ Material of Floor } \\
\hline & \multicolumn{2}{|l|}{ Total } & \multicolumn{2}{|l|}{ Rural } & \multicolumn{2}{|l|}{ Urban } \\
\hline & Absolute & Per cent & Absolute & Per cent & Absolute & Per cent \\
\hline 1 & 2 & 3 & 4 & 5 & 6 & 7 \\
\hline All Material & 449,366 & 100.00 & 275,867 & 61.39 & 173,499 & 38.61 \\
\hline Mud & 122,026 & 27.16 & 105,056 & 23.38 & 16,970 & 3.78 \\
\hline Wood/ Bamboo & 418 & 0.09 & 250 & 0.06 & 168 & 0.04 \\
\hline Burnt Brick & 52,967 & 11.79 & 39,792 & 8.86 & 13,175 & 2.93 \\
\hline Stone & 47,940 & 10.67 & 14,490 & 3.22 & 33,450 & 7.44 \\
\hline Cement & 200,537 & 44.63 & 106,498 & 23.70 & 94,039 & 20.93 \\
\hline Mosaic/ Floor tiles & 23,857 & 5.31 & 9,228 & 2.05 & 14,629 & 3.26 \\
\hline Any other material & 1,621 & 0.36 & 553 & 0.12 & 1,068 & 0.24 \\
\hline
\end{tabular}

Source: http://www.censusindia.gov.in/2011census/hlo/hlo_table/hlo_table_Haryana.html

Table 10: Ownership /Dwelling Rooms in the Census Houses Occupied by Women Headed Households

\begin{tabular}{|c|c|c|c|c|c|c|c|c|c|}
\hline \multirow{3}{*}{$\begin{array}{l}\text { Number of } \\
\text { Rooms }\end{array}$} & \multicolumn{9}{|c|}{ Ownership of the House } \\
\hline & \multicolumn{3}{|c|}{ Owned } & \multicolumn{3}{|c|}{ Rented } & \multicolumn{3}{|c|}{ Any Other } \\
\hline & Total & Rural & Urban & Total & Rural & Urban & Total & Rural & Urban \\
\hline 1 & 2 & 3 & 4 & 5 & 6 & 7 & 8 & 9 & 10 \\
\hline No exclusive room & 1.20 & 1.30 & 1.06 & 0.17 & 0.06 & 0.35 & 0.10 & 0.08 & 0.14 \\
\hline One room & 18.88 & 21.41 & 14.86 & 2.75 & 0.64 & 6.11 & 0.69 & 0.53 & 0.94 \\
\hline Two rooms & 31.58 & 34.06 & 27.63 & 1.98 & 0.50 & 4.33 & 0.48 & 0.32 & 0.74 \\
\hline Three rooms & 20.13 & 20.06 & 20.26 & 0.79 & 0.16 & 1.78 & 0.20 & 0.12 & 0.33 \\
\hline Four rooms & 11.89 & 11.75 & 12.11 & 0.33 & 0.06 & 0.76 & 0.07 & 0.06 & 0.10 \\
\hline Five rooms & 4.52 & 4.67 & 4.26 & 0.08 & 0.02 & 0.19 & 0.03 & 0.02 & 0.04 \\
\hline Six rooms \& above & 4.06 & 4.17 & 3.89 & 0.05 & 0.02 & 0.12 & 0.02 & 0.01 & 0.02 \\
\hline Total & 92.26 & 97.42 & 84.06 & 6.15 & 1.45 & 13.63 & 1.59 & 1.13 & 2.30 \\
\hline
\end{tabular}

Source: http://www.censusindia.gov.in/2011census/hlo/hlo_table/hlo_table_Haryana.html

This table 10 reflects ownership status of the women headed households with availability of dwelling units. It is reported that 97.42 per cent in rural and 84.06 per cent households are having houses of their own.

Table 11: Availability of Drinking Water for Women Headed Households

\begin{tabular}{|l|l|l|l|l|l|l|l|}
\hline \multirow{2}{*}{$\begin{array}{l}\text { Total } \\
\text { Rural/ } \\
\text { Urban }\end{array}$} & \multirow{2}{*}{$\begin{array}{l}\text { Number } \\
\text { Households }\end{array}$} & $\begin{array}{l}\text { of } \\
\text { Within premises }\end{array}$ & Absolute & Per cent & Absolute & Per cent & \multicolumn{2}{|l|}{ Absolute } & Per cent \\
\hline $\mathbf{1}$ & $\mathbf{2}$ & $\mathbf{3}$ & $\mathbf{4}$ & $\mathbf{5}$ & $\mathbf{6}$ & $\mathbf{7}$ & $\mathbf{8}$ \\
\hline Total & 449,366 & 296,478 & 65.98 & 96,527 & 21.48 & 56,361 & 12.54 \\
\hline Rural & 275,867 & 151,225 & 54.82 & 77,177 & 27.98 & 47,465 & 17.21 \\
\hline Urban & 173,499 & 145,253 & 83.72 & 19,350 & 11.15 & 8,896 & 5.13 \\
\hline
\end{tabular}

Source: http://www.censusindia.gov.in/2011census/hlo/hlo_table/hlo_table_Haryana.html

Household amenities data as per Census 2011 on women headed households presents the status for availability of basic amenity i.e. water under three parameters. First is 'within premises', second 'near premises' (for urban it is considered within a range of 100 meters in Urban areas and within a distance of 500 meters in the case of Rural areas from the premises) and lastly 'away' (if source is 100 meters or more in urban areas and 500 meters or more in rural areas from the premises). 65.98 per cent households are having the water facility with the premises. In rural, 27.98 per cent \& 17.21 per cent households having facility as near the premises and away. 
International Journal of Innovative Research in Engineering \& Management (IJIREM)

ISSN: 2350-0557, Volume-8, Issue-3, May 2021

https://doi.org/10.21276/ijirem.2021.8.3.2

www.ijirem.org

Table 12: Type of Fuel used by Women Headed Households

\begin{tabular}{|c|c|c|c|c|c|c|}
\hline \multirow[t]{2}{*}{ Household by Type of Fuel } & \multicolumn{3}{|l|}{ Absolute } & \multicolumn{3}{|c|}{ Percentage } \\
\hline & Total & Rural & Urban & Total & Rural & Urban \\
\hline 1 & 2 & 3 & 4 & 5 & 6 & 7 \\
\hline Number of households & 449,366 & 275,867 & 173,499 & 100.00 & 100.00 & 100.00 \\
\hline Fire-wood & 115,887 & 93,749 & 22,138 & 25.79 & 33.98 & 12.76 \\
\hline Crop residue & 63,455 & 59,809 & 3,646 & 14.12 & 21.68 & 2.10 \\
\hline Cowdung cake & 64,182 & 54,428 & 9,754 & 14.28 & 19.73 & 5.62 \\
\hline Coal, Lignite, Charcoal & 432 & 216 & 216 & 0.10 & 0.08 & 0.12 \\
\hline Kerosene & 3,932 & 957 & 2,975 & 0.88 & 0.35 & 1.71 \\
\hline LPG/PNG & 199,312 & 65,474 & 133,838 & 44.35 & 23.73 & 77.14 \\
\hline Electricity & 115 & 74 & 41 & 0.03 & 0.03 & 0.02 \\
\hline Biogas & 894 & 571 & 323 & 0.20 & 0.21 & 0.19 \\
\hline Any other & 204 & 70 & 134 & 0.05 & 0.03 & 0.08 \\
\hline No cooking & 953 & 519 & 434 & 0.21 & 0.19 & 0.25 \\
\hline
\end{tabular}

Source: http://www.censusindia.gov.in/2011census/hlo/hlo_table/hlo_table_Haryana.html

Data on type of fuel used for cooking presents that out of 449,366 households, 44.35 per cent are making use of LPG/PNG
(Liquefied Petroleum Gas/Piped Natural Gas) in total; 23.73 per cent in rural and 77.14 per cent in urban. (Table -12)

Table 13: Availability of Latrine Facility in the Houses headed by Women Households

\begin{tabular}{|c|c|c|c|c|c|}
\hline \multirow{2}{*}{$\begin{array}{l}\text { Total/ } \\
\text { Rural/ } \\
\text { Urban }\end{array}$} & \multirow[t]{2}{*}{$\begin{array}{l}\text { Number } \\
\text { Households }\end{array}$} & \multicolumn{2}{|c|}{ of Having latrine facility within the premises } & \multicolumn{2}{|c|}{\begin{tabular}{|l|l|}
$\begin{array}{l}\text { Not having latrine facility withir } \\
\text { premises }\end{array}$ & \\
\end{tabular}} \\
\hline & & Absolute & Per cent & Absolute & Per cent \\
\hline 1 & 2 & 3 & 4 & 5 & 6 \\
\hline Total & 449,366 & 310,343 & 69.06 & 139,023 & 30.94 \\
\hline Rural & 275,867 & 154,566 & 56.03 & 121,301 & 43.97 \\
\hline Urban & 173,499 & 155,777 & 89.79 & 17,722 & 10.21 \\
\hline
\end{tabular}

Source:http://www.censusindia.gov.in/2011census/hlo/hlo_table/hlo_table_Haryana.html

The status of sanitation, health and hygiene condition can very well be assumed from the available data on households having availability of latrine facility. Out of houses occupied and headed by women, in 69.06 per cent of the households are having latrine facility within the premises. The facility exists for 56.03 per cent of the households in rural and 89.79 per cent in urban. (Table 13)

Table 14: Women Headed Households utilizing Banking Facilities

\begin{tabular}{|l|l|l|l|}
\hline Total Number of ...... & Total & Rural & Urban \\
\hline $\mathbf{1}$ & $\mathbf{2}$ & $\mathbf{3}$ & $\mathbf{4}$ \\
\hline Female Headed Households & 449,366 & 275,867 & 173,499 \\
\hline Availing Banking Facilities & $295,347(65.73)$ & $175,173(63.50)$ & $120,174(69.26)$ \\
\hline
\end{tabular}

Source: http://www.censusindia.gov.in/2011census/hlo/hlo_table/hlo_table_Haryana.html

Above table is confirmation to the fact that there is awareness about banking services among the women headed households.
However, in total this service is availed by 65.73 per cent of the households. 
Table 15 (a): Women Headed Households in Possession of Specified Assets

\begin{tabular}{|c|c|c|c|c|c|c|c|}
\hline \multirow{2}{*}{\multicolumn{2}{|c|}{ Households in Possession of Assets }} & \multicolumn{3}{|c|}{ Absolute } & \multicolumn{3}{|c|}{ Percentage } \\
\hline & & Total & Rural & Urban & Total & Rural & Urban \\
\hline \multicolumn{2}{|c|}{1} & 2 & 3 & 4 & 5 & 6 & 7 \\
\hline \multicolumn{2}{|c|}{ Number of households } & 449,366 & 275,867 & 173,499 & 100.00 & 100.00 & 100.00 \\
\hline \multicolumn{2}{|c|}{ Radio/Transistor } & 63,299 & 36,697 & 26,602 & 14.09 & 13.30 & 15.33 \\
\hline \multicolumn{2}{|c|}{ Television } & 295,010 & 154,190 & 140,820 & 65.65 & 55.89 & 81.16 \\
\hline \multicolumn{2}{|c|}{ Computer/Laptop (With Internet) } & 18,431 & 2,889 & 15,542 & 4.10 & 1.05 & 8.96 \\
\hline \multicolumn{2}{|c|}{ Computer/Laptop (Without Internet) } & 32,431 & 13,164 & 19,267 & 7.22 & 4.77 & 11.10 \\
\hline \multirow{3}{*}{ Telephone } & Landline & 19,437 & 8,942 & 10,495 & 4.33 & 3.24 & 6.05 \\
\hline & Mobile & 278,154 & 169,613 & 108,541 & 61.90 & 61.48 & 62.56 \\
\hline & Both & 31,996 & 10,755 & 21,241 & 7.12 & 3.90 & 12.24 \\
\hline \multicolumn{2}{|c|}{ Bicycle } & 162,133 & 92,599 & 69,534 & 36.08 & 33.57 & 40.08 \\
\hline \multicolumn{2}{|c|}{ Scooter/Motorcycle/Moped } & 124,129 & 61,479 & 62,650 & 27.62 & 22.29 & 36.11 \\
\hline \multicolumn{2}{|c|}{ Car/Jeep/Van } & 34,988 & 11,506 & 23,482 & 7.79 & 4.17 & 13.53 \\
\hline
\end{tabular}

Source: http://www.censusindia.gov.in/2011census/hlo/hlo_table/hlo_table_Haryana.html

Luxuries need has become a routine affair for the households able to afford on date. The data on Assets as per Census 2011 provides the availability of specified assets in possession of the households. Possession of television is noticed in 65.65 per cent of the households followed by mobile with 61.90 per cent. Second last row provides information about the households which do not possess any of these specified assets and last row gives handful information about households having television, computer/laptop, telephone/mobile and scooter/car in their possession. [Table 15 (a) and (b)]

Table 15 (b): Women Headed Households in not in Possession of Specified Assets \& having collectively certain Assets

\begin{tabular}{|l|l|l|l|l|l|l|}
\hline \multicolumn{2}{|c|}{ Households in Possession of Assets } & \multicolumn{4}{l|}{ Absolute } & \multicolumn{3}{l|}{ Percentage } \\
\cline { 2 - 8 } & Total & Rural & Urban & Total & Rural & Urban \\
\hline $\mathbf{1}$ & $\mathbf{2}$ & $\mathbf{3}$ & $\mathbf{4}$ & $\mathbf{5}$ & $\mathbf{6}$ & $\mathbf{7}$ \\
\hline None of the Specified Assets & 65,964 & 52,007 & 13,957 & 14.68 & 18.85 & 8.04 \\
\hline $\begin{array}{l}\text { Households with TV, Computer/Laptop, } \\
\text { Telephone/Mobile phone and Scooter/Car }\end{array}$ & 30,612 & 5,632 & 24,980 & 6.81 & 2.04 & 14.40 \\
\hline
\end{tabular}

Source: http://www.censusindia.gov.in/2011census/hlo/hlo_table/hlo_table_Haryana.html

\section{CONCLUSION}

The study reveals that there are no much better conditions of women household headed in the present rural agrarian economy. After women empowerment implementation or liberalized economic system of Indian economy the women household head have lacking the basic facilities and not using in proper way of banking facilities regarding their economic conditions. There is need to further improvement in the policies which are run by the govt. and other institutions regarding women empowerment and their welfare. Women headed households occupying houses made up of burnt brick is more in rural (53.65 per cent) in comparison to urban ( 33.23 per cent). Only 17 percent women are taking final decision regarding selling and purchasing of animals in the present agrarian economy in rural areas. In the last it can be said that after a long time had been spent there is better improvement in conditions of women in Indian agrarian economy concerned.

\section{REFERENCES}

[1] Bayan, Cavite. "Factors Affecting Participation of Women in Household Decision Making: Implication for Family Welfare and Agriculture Development." Socio Economic Voice, JuneJuly (2014): 1 - 11. Accessed October 29, 2017. url: http://www.indiastat.com.

[2] Farid, K.S., Mozumdar, L., Kabir, M.S. and Goswami, U.K. "Nature and Extent of Rural Women's Participation in
Agricultural and Non-Agricultural Activities.” Agricultural Research Communication Centre 29, No. 4 (2009): 254 - 259.

[3] Goswami, Chandrama. "Female Agriculture Worker in Asam: A case Study of Darrange District." International Journal of Scientific and Research Publications 3, No. 2 (2013): 1 - 5.

[4] Hoque, Mahmuda and Itohara, Yoshihito. "Participation and Decision Making Role of Rural Women in Economic Activities: A Comparative Study for Members and Non Members of the Micro-Credit Organizations in Bangladesh." Journal of Social Sciences 4, No. 3(2008):

[5] Hussain, B A and Hussain, N A. "Decision Making Power among Rural Women at Gross-Root Level." Research Journal of Finance and Accounting 2, No. 5 (2011):

[6] H \& HH Series, Census of India 2011, accessed on September 15, 2017, http://www.censusindia.gov.in/2011census/hlo/ hlo_table/hlo_table_Haryana.html.

[7] Kumar, Debendra and Ahmed, Aijazuddin. "Female Participation in Economic Activity: A Geographical Perspective with Special Reference to Rural Areas in India." The Indian Geographical Journal, 59 (1984): 262 - 267.

[8] Kumar, Mahata, D., and Rai, A. Kumar. "Female Work Force Participation and Women Empowerment in Haryana." International Journal of Social, Behavior, Educational, Economic, Business and Industrial Engineering 11, No. 4 (2017): 1018-1023.

[9] Mohanty, S.R., Bijaylaxmi, D. and Mohanty, T. "Capacity Building and Decision -Making of Rural Odisha Women through Participation in Micro Enterprises." International Journal of Scientific and Research Publications 3, No. 7 
International Journal of Innovative Research in Engineering \& Management (IJIREM)

ISSN: 2350-0557, Volume-8, Issue-3, May 2021

https://doi.org/10.21276/ijirem.2021.8.3.2

www.ijirem.org

(2013): $1-8$. Accessed on October 16, 2017. url: http://www.ijsp.org.

[10] Santosh, B. and Charan B. "Gender Issues: The Role of Women in Agriculture Sector in India." International Journal of Marketing, Financial Services and Management Research 2, No. 9 (2013): 134 - 146.

[11] Sharma S., Rao, P.K. and Sharma, R. "Role of Women in Decision -Making Related to Farm: A Study of Jammu District of J \& K State." International Journal of Scientific and Research Publications 3, No. 1 (2013): 1 - 4.
[12] Singh, Ishwar. "Participation of Rural Female in Various Economic Activities: with Special Reference to Haryana." International Journal of Research in IT \& Management 1, No. 7 (2011):

[13] Tsegaye D., Dessalegn T., Yimam A. and Kefale, M. "Extent of Rural Women Participation and Decision Making in Seed Production Activities." Global Advanced Research Journal of Agricultura

[14] 1 Science 1, No. 7 (2012): 186 - 190. 